\title{
On the attribution of black and brown carbon light absorption using the Ångström exponent
}

\author{
D. A. Lack ${ }^{1,2}$ and J. M. Langridge ${ }^{1,2, *}$ \\ ${ }^{1}$ NOAA Earth System Research Laboratory, Chemical Sciences Division, 325 Broadway, Boulder, CO 80304, USA \\ ${ }^{2}$ Cooperative Institute for Research in Environmental Sciences, University of Colorado, 216 UCB, Boulder, CO 80309, USA \\ * now at: Observation Based Research, Met Office, Fitzroy Road, Exeter, EX1 3PB, UK
}

Correspondence to: D. A. Lack (daniel.lack@noaa.gov)

Received: 28 May 2013 - Published in Atmos. Chem. Phys. Discuss.: 11 June 2013

Revised: 27 August 2013 - Accepted: 24 September 2013 - Published: 31 October 2013

\begin{abstract}
The absorption Ångström exponent (AAE) of externally mixed black carbon $\left(\mathrm{BC}_{\mathrm{Ext}}\right)$, or $\mathrm{BC}$ internally mixed with non-absorbing material $\left(\mathrm{BC}_{\text {Int }}\right)$, is often used to determine the contribution of brown carbon $(\mathrm{BrC})$ light absorption at short visible wavelengths. This attribution method contains assumptions with uncertainties that have not been formally assessed. We show that the potential range of AAE for $\mathrm{BC}_{\mathrm{Ext}}$ (or $\mathrm{BC}_{\mathrm{Int}}$ ) in the atmosphere can reasonably lead to $+7 \%$ to $-22 \%$ uncertainty in $\mathrm{BC}_{\text {Ext }}$ (or $\mathrm{BC}_{\text {Int }}$ ) absorption at short wavelengths derived from measurements made at longer wavelengths, where $\mathrm{BrC}$ is assumed not to absorb light. These uncertainties propagate to errors in the attributed absorption of BrC. For uncertainty in attributed $\mathrm{BrC}$ absorption to be $\leq \pm 33 \%, 23 \%$ to $41 \%$ of total absorption must be sourced from BrC. These uncertainties would be larger if absorption by dust were also to be considered due to additional AAE assumptions. For data collected during a biomass-burning event, the mean difference between measured and $\mathrm{AAE}$ attributed $\mathrm{BrC}$ absorption was found to be $34 \%$ - an additional uncertainty in addition to the theoretical uncertainties presented. In light of the potential for introducing significant and poorly constrained errors, we caution against the universal application of the AAE method for attributing $\mathrm{BrC}$ absorption.
\end{abstract}

\section{Introduction}

The Ångström exponent was originally developed to describe the wavelength dependence of visible light extinction by atmospheric particles (Ångström, 1929). The Ångström exponent for extinction is mostly influenced by particle size and is often used to differentiate large particles (e.g. desert dust, sea salt) from fine-mode particles (e.g. anthropogenic organics, sulfates and nitrates) in atmospheric samples (Bergstrom et al., 2007; Meloni et al., 2006). Equation (1) shows the calculation of the Ångström exponent using a pair of observations at two different wavelengths:

$\operatorname{AE}\left(\lambda_{1} \lambda_{2}\right)=\frac{\ln \left(\frac{b_{\text {Optical }}\left(\lambda_{1}\right)}{b_{\text {Optical }}\left(\lambda_{2}\right)}\right)}{\ln \left(\frac{\lambda_{1}}{\lambda_{2}}\right)}$,

where $b_{\text {Optical }}$ is the optical coefficient of interest, such as particle light extinction, absorption, single scattering albedo (SSA) or optical depth, at wavelength $\lambda$, where $\lambda_{2}>\lambda_{1}$.

Black carbon is the primary absorbing aerosol component in the atmosphere. The absorption Angström exponent (AAE) for externally mixed black carbon $\left(\mathrm{BC}_{\mathrm{Ext}}\right)$ is predicted to be wavelength-independent $(\mathrm{AAE}=1)$ for particles $<50 \mathrm{~nm}$ diameter (Moosmüller et al., 2011; Moosmüller and Arnott, 2009; Bergstrom et al., 2002, and references therein). However, the AAE for ambient particles (measured between a short and long visible wavelength) has often been observed to be larger than 1 . There are a number of factors that contribute to these observations including enhanced absorption by $\mathrm{BC}$ internally mixed with non-absorbing material, and/or absorption by non-BC absorbers such as brown carbon $(\mathrm{BrC})$ or desert dust (Russell et al., 2010; Kirchstetter et al., 2004). These mechanisms are treated in turn below.

$\mathrm{BC}$ absorption under dry atmospheric conditions can in theory be enhanced at all wavelengths by the presence of transparent coatings (Bond et al., 2006; Jacobson, 2001; 
Bohren and Huffman, 1983; Fuller et al., 1999). The mechanism for this enhancement is one in which the coating acts as a lens to focus radiation into the absorbing $\mathrm{BC}$ core. Absorption enhancements of this nature have been observed in some laboratory and field studies (e.g. Cappa et al., 2012; Cross et al., 2010; Schnaiter et al., 2005; Lack et al., 2009, 2012b). Theoretical calculations have bounded the likely range of $\mathrm{AAE}$ for internally mixed $\mathrm{BC}\left(\mathrm{BC}_{\mathrm{Int}}\right)$. They have shown that the AAE can vary from a baseline of 1 to an upper limit of $\sim 1.7$, depending on the size and optical properties of the core and non-absorbing coating and the wavelength pairs used to determine AAE (Gyawali et al., 2009; Lack and Cappa, 2010).

Non-BC absorbers could potentially enhance AAE more significantly, although it should be noted that the spectral variability of absorption by $\mathrm{BrC}$ or dust may not be captured well by the AAE model (e.g. Updyke et al., 2012). Values of $\mathrm{AAE}$ for $\mathrm{BrC}$ up to 9.5 have been observed (wavelength pairs: $400,700 \mathrm{~nm}$ ) (Andreae and Gelencser, 2006, and references therein; Rizzo et al., 2011; Flowers et al., 2010; Lewis et al., 2008; Corr et al., 2012) while AAEs for desert dust range from 2.5 to 6.0 (wavelength pairs: $467 \mathrm{~nm}, 660 \mathrm{~nm}$ ) (e.g. Weinzierl et al., 2011).

In this paper we provide a theoretical discussion on the method of using assumed AAEs to attribute total absorption to $\mathrm{BC}$ and $\mathrm{BrC}$ (Sect. 2). We then provide a case study for this method using measurements from a biomass burning plume, which contains absorption by $\mathrm{BC}$, internal mixing and $\mathrm{BrC}$ (Sect. 3). Dust is excluded from the following discussions for two reasons. The first is to provide focus and clarity to the theoretical description of the method. The consideration of dust, while adding complexity, does not significantly change the approach to considering uncertainty propagation with the AAE method. Second, this study utilizes a unique experimental data set which does not include absorption by dust, limiting our ability to test dust absorption attribution methods at present.

\section{2 Ångström attribution of absorption}

\subsection{Methods}

The AAE has often been used in a simple method for attributing short visible wavelength absorption to $\mathrm{BC}$ and non-BC sources. The attribution method utilizes a pair of measurements usually spanning extremes of the visible wavelength spectrum $(\sim 400 \mathrm{~nm}$ to $\sim 700 \mathrm{~nm})$. Absorption at the longer wavelength is assumed to be due only to dry $\mathrm{BC}_{\mathrm{Ext}}$, or dry $\mathrm{BC}_{\text {Int }}$. Unless the measurements exclude internally mixed material (e.g. by pre-conditioning aerosol to remove coatings), the measurement will represent absorption by $\mathrm{BC}_{\text {Int }}$. This absorption measurement is extrapolated to the shorter wavelength using an assumed AAE, most commonly 1 . The difference between the measured and attributed absorption at

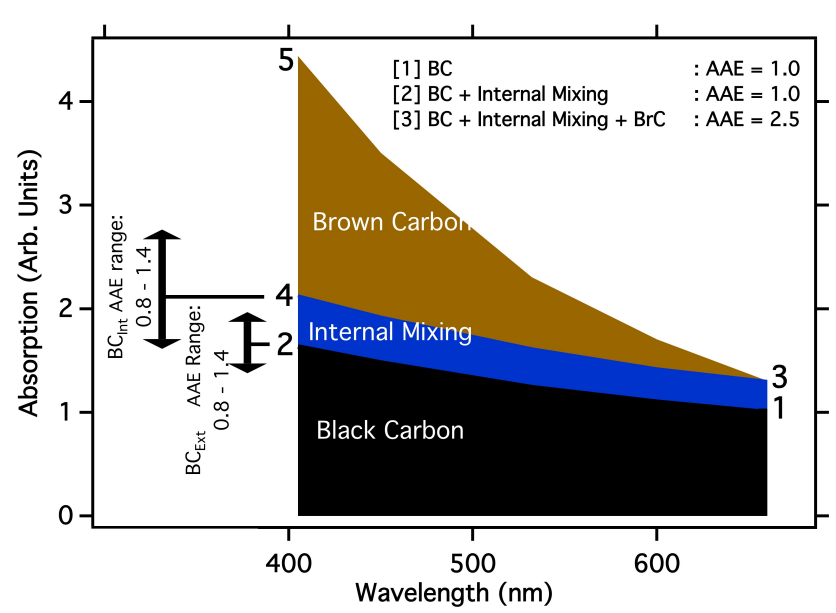

Fig. 1. Illustration of the attribution of absorption using the absorption Ångström exponent. We assume this system does not contain any dust. The absorption by $\mathrm{BC}_{\text {Ext }}$ is assumed to have an $\mathrm{AAE}=1$, line 1-2. Absorption by $\mathrm{BC}$ internally mixed with non-absorbing material $\left(\mathrm{BC}_{\text {Int }}\right)$ is often assumed to have an $\mathrm{AAE}=1$, line 3-4. In this example the AAE of all ambient particles, including brown carbon, is 2.5 , line $3-5$. The $\mathrm{AAE}$ for $\mathrm{BC}_{\mathrm{Ext}}$ and $\mathrm{BC}_{\text {Int }}$ may range from 0.8 to 1.4 , which is indicated by the uncertainty arrows on points 2 and 4 .

the short wavelength is then attributed to absorption by non$\mathrm{BC}$ entities.

Figure 1 shows an illustration of this method. The figure was constructed by arbitrarily setting the absorption level of $\mathrm{BC}_{\text {Ext }}$ to 1 at $658 \mathrm{~nm}$ and assuming an $\mathrm{AAE}$ of 1 for $\mathrm{BC}_{\text {Ext }}$ (line 1-2). Absorption enhancement by internal mixing of $\mathrm{BC}$ with non-absorbing material, with an $\mathrm{AAE}$ of 1 (see discussion below), was added to the $\mathrm{BC}_{\mathrm{Ext}}$ absorption (line 3-4). Absorption due to $\mathrm{BrC}$ was represented using an $\mathrm{AAE}=2.5$ (line 3-5) assuming no $\mathrm{BrC}$ absorption at $658 \mathrm{~nm}$. Studies that utilize this attribution method would commonly have absorption measurements at points 3 and 5 , and extrapolate absorption to point 4 .

More complex multi-wavelength methods for absorption attribution have been reported and mostly use satellite, aircraft, or ground-based measurements of multi-spectral aerosol optical depth, actinic flux, scattering, or back scattering and extinction (Tesche et al., 2011; Arola et al., 2011; Kaufman et al., 2002; Schuster et al., 2005; Bergstrom et al., 2004; Corr et al., 2012). These methods use radiation models and complex Mie modelling retrievals to determine particle type (fine vs. coarse mode), and multi-spectral particle refractive index, SSA and absorption. Despite their greater complexity, some of these methods still rely on assumed values of the AAE for BC (Arola et al., 2011; Kaufman et al., 2002; Schuster et al., 2005). The advantages of these methods are their expansive coverage via satellite and aircraft platforms, and wide wavelength coverage. However retrievals and subsequent data products can be subject to significant 
uncertainty that is difficult to quantify (Li et al., 2009). Here we focus on the simple AAE approach on account of its widespread use in peer-reviewed studies (Bahadur et al., 2012; Cazorla et al., 2013; Chung et al., 2012; Clarke et al., 2007; Esposito et al., 2012; Favez et al., 2009; Fialho et al., 2005; Gadhavi and Jayaraman, 2010; Herich et al., 2011; McNaughton et al., 2011; Sandradewi et al., 2008a, b; Wang et al., 2013; Yang et al., 2009).

\subsection{Uncertainties in attribution of $\mathrm{BC}$}

Uncertainties in the AAE attribution method primarily arise from the choice of $\mathrm{AAE}$ used to characterize $\mathrm{BC}_{\mathrm{Ext}}$ or $\mathrm{BC}_{\text {Int }}$. As stated previously, the $\mathrm{AAE}$ for $\mathrm{BC}_{\mathrm{Ext}}$ is approximately 1 for particles $<50 \mathrm{~nm}$ in diameter, but can range from 0.8 to 1.1 for diameters of 50-200 nm (Gyawali et al., 2009). These larger $\mathrm{BC}$ particle sizes can exist in the atmosphere due to coagulation and collapse of smaller $\mathrm{BC}_{\mathrm{Ext}}$ spherules (e.g. Cross et al., 2010; Zhang et al., 2008), or from direct formation during inefficient combustion (Schwarz et al., 2008). A recent study also suggested a lower limit of $\mathrm{AAE}=0.55$ for atmospheric "elemental carbon" (a term functionally similar to BC) (Bahadur et al., 2012), which is included here for completeness. Despite this potential variability in the AAE for $\mathrm{BC}_{\mathrm{Ext}}$, an $\mathrm{AAE}=1$ is a commonly used community standard.

For $\mathrm{BC}_{\text {Int }}$ the situation is somewhat different. As described previously, the theoretical $\mathrm{AAE}$ for $\mathrm{BC}_{\text {Int }}$ can range from the uncoated baseline to $\sim 1.7$ (Gyawali et al., 2009; Lack and Cappa, 2010). In contrast, Bahadur et al. (2012) assumed that internal mixtures did not affect the AAE and used an AAE for $\mathrm{BC}_{\mathrm{Int}}=0.55$. Analysis of a range of atmospheric measurements of the AAE for aerosol sourced from fresh fossil fuel burning and urban pollution (where the dominant absorber was BC) shows an average value for the AAE of $1.1 \pm 0.3$ $(1 \sigma)$ derived using the wavelength pair $467 \mathrm{~nm}$ and $660 \mathrm{~nm}$ (Lack et al., 2008; Clarke et al., 2007; Virkkula et al., 2005; Rosen et al., 1978; Bergstrom et al., 2002, 2007; Kirchstetter et al., 2004). This suggests that the AAE extremes presented (0.55 and 1.7) are likely not common in the atmosphere for $\mathrm{BC}_{\mathrm{Ext}}$ and $\mathrm{BC}_{\text {Int }}$, and serve here as extreme boundaries only. Although there is variability in the AAE, these studies have been used previously to support the use of an $\mathrm{AAE}=1$ for $\mathrm{BC}_{\mathrm{Ext}}$ (Bond et al., 2013), and it is common to assume that the AAE for $\mathrm{BC}_{\text {Int }}$ is equal to that of $\mathrm{BC}_{\mathrm{Ext}}$. These studies provide evidence that although an $\mathrm{AAE}$ of 1 may be an accepted average for $\mathrm{BC}_{\mathrm{Ext}}$ and $\mathrm{BC}_{\mathrm{Int}}$, an uncertainty range should be considered and propagated through any absorption attribution procedure performed (this range is represented in Fig. 1 by the vertical arrow on points 2 and 4).

Figure 2a (grey line) shows the uncertainty in attributed short wavelength $\mathrm{BC}_{\mathrm{Ext}}$ and $\mathrm{BC}_{\mathrm{Int}}$ absorption arising from use of an AAE of 1. It should be interpreted as follows: if an average $\mathrm{AAE}$ of 1 is used to attribute short wavelength $\mathrm{BC}_{\text {Int }}$ absorption from a long wavelength measurement, when in
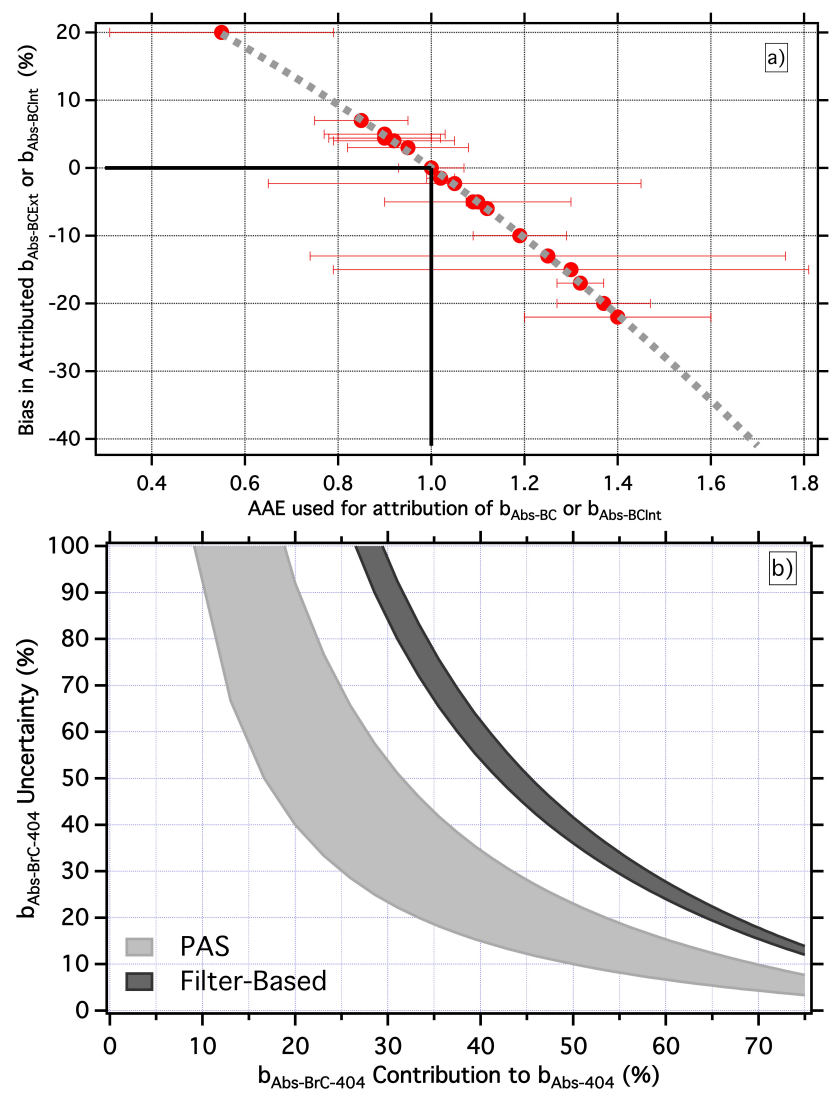

Fig. 2. (a) Theoretical uncertainties in attributed $\mathrm{BC}_{\mathrm{Ext}}$ (or $\mathrm{BC}_{\text {Int }}$ ) $404 \mathrm{~nm}$ absorption when $\mathrm{AAE}=1$, rather than another value within the possible range suggested for $\mathrm{BC}_{\mathrm{Ext}}$ or $\mathrm{BC}_{\mathrm{Int}}$. Red data show average AAE measured for particles assumed to be mostly $\mathrm{BC}$ ( $y$ axis for red data forced to match black line for clarity). (b) Uncertainty in attributed $\mathrm{BrC}$ absorption (at $404 \mathrm{~nm}$ ) based on the uncertainties in AAE used for the absorption attribution process and the uncertainties in the absorption measurement method.

fact the AAE was 1.2, then the attributed absorption will be low by $10 \%$. In most circumstances practitioners of the $\mathrm{AAE}$ method do not know what the true $\mathrm{AAE}$ for $\mathrm{BC}_{\mathrm{Ext}}$ or $\mathrm{BC}_{\text {Int }}$ is, and use of an $\mathrm{AAE}=1$ is the common default. Using the widest ranges of $\mathrm{BC}_{\mathrm{Ext}}$ or $\mathrm{BC}_{\mathrm{Int}} \mathrm{AAE}$ reported in literature, attribution biases of $+20 \%$ to $-40 \%$ are possible. Using a more plausible experimentally based range derived from the studies referenced above of $1.1 \pm 0.3$ (Fig. 2a, red markers), a more likely uncertainty in attributed short wavelength $\mathrm{BC}_{\mathrm{Ext}}$ or $\mathrm{BC}_{\text {Int }}$ absorption is $+7 \%$ to $-22 \%$. This uncertainty will contribute to uncertainty in attributed $\mathrm{BrC}$ absorption, the magnitude of which will depend on the total level of absorption.

\subsection{Uncertainties in attribution of $\mathrm{BrC}$}

Following determination of the short wavelength $\mathrm{BC}_{\text {Int }} \mathrm{ab}-$ sorption using the Ångström attribution method, BrC absorption can be attributed. The uncertainty associated with 
derived $\mathrm{BrC}$ absorption can be assessed by combining uncertainty in the AAE attribution method with the uncertainty in the absorption measurements themselves. This resulting total uncertainty depends on the fractional contribution of $\mathrm{BrC}$ to the total aerosol absorption.

First we consider uncertainties in the AAE attribution method. In Sect. 2 we showed that the uncertainty in shortwavelength absorption by $\mathrm{BC}_{\text {Int }}$ determined by extrapolation using an $\mathrm{AAE}=1$ ranged from $+7 \%$ to $-22 \%$. To simplify the following analysis, rather than report asymmetric uncertainties, we report uncertainty in the format high (low). For example, the uncertainty in attributed $\mathrm{BC}_{\text {Int }}$ absorption is represented as $\pm 22 \%( \pm 7 \%)$.

Second we consider experimental uncertainties. For this analysis we assume absorption measurements were made using the photoacoustic aerosol absorption spectrometer (PAS) technique, with an uncertainty of $\pm 5 \%$ (Lack et al., 2009, 2012a). We investigate a system where we assume that the PAS was used to measure $\mathrm{BC}_{\text {Int }}$ absorption at $658 \mathrm{~nm}$ $( \pm 5 \%)$, which was then used to attribute $\mathrm{BC}_{\text {Int }}$ absorption at $404 \mathrm{~nm}$. The AAE and PAS measurement uncertainties are treated independently and propagated in quadrature yielding an uncertainty range in attributed $\mathrm{BC}_{\mathrm{Int}}$ absorption at $404 \mathrm{~nm}$ of $\pm 22.6 \%( \pm 8.6 \%)$. To this estimate, we add the uncertainty in PAS-measured total absorption $\left(\mathrm{BC}_{\text {Int }}+\mathrm{BrC}\right.$ absorption) at $404 \mathrm{~nm}( \pm 5 \%)$, which yields a total uncertainty range for attributed $\mathrm{BrC}$ absorption at $404 \mathrm{~nm}$ of $\pm 23 \%$ $( \pm 10 \%)$. It is clear that the most significant contributor to the total uncertainty arises from the choice of AAE used.

This analysis indicates that in order for the uncertainty in attributed $\mathrm{BrC}$ absorption at $404 \mathrm{~nm}$ to be less than $\pm 100 \%$, the absolute contribution from $\mathrm{BrC}$ absorption must be at least $23 \%(10 \%)$ of that from $\mathrm{BC}_{\mathrm{Int}}$, or $19 \%$ of the total absorption. Figure $2 \mathrm{~b}$ shows the relationship between the uncertainty in attributed $\mathrm{BrC}$ absorption and the contribution of $\mathrm{BrC}$ to total absorption when using the PAS technique. We note that if filter-based methods for measuring absorption are used (e.g. Aethelometer ${ }^{\circledR}$ or particle soot absorption photometer), which have estimated uncertainties of the order of $25 \%$ (Bond et al., 2013), the minimum contribution of $\mathrm{BrC}$ to total absorption must be larger to provide similar uncertainties (these results are also shown in Fig. 2b). This estimate neglects the influence of additional suspected biases that may add further uncertainty to filter-based methods (Lack et al., 2008; Subramanian et al., 2007).

\section{A case study for $\mathrm{BrC}$ attribution}

\subsection{Methods}

This section provides experimental details of a case study in which detailed optical property measurements are used, for the first time, to compare $\mathrm{BrC}$ absorption attributed using the AAE method to that derived using a fully independent method. Data were collected during a dense biomass burning event, where emissions were sampled $24 \mathrm{~h}$ after the start of a ponderosa pine forest fire near Boulder, Colorado, during September 2010. Details of this data set can be found in Lack et al. (2012b) and are only briefly summarized here.

Particle emissions were dominated by BC (measured using a soot particle photometer, Schwarz et al., 2008) and organics (measured using an aerosol mass spectrometer, AMS, Bahreini et al., 2009). Organic compounds consistently accounted for $>90 \%$ of non-BC particle mass $\left(m_{\text {non-BC }}\right)$. A PAS measured dry total absorption at $658 \mathrm{~nm}$ and $404 \mathrm{~nm}$ $\left(b_{\text {Abs-658 }}, b_{\mathrm{Abs}-404}\right)$ and thermal-denuded absorption at $404 \mathrm{~nm}\left(b_{\mathrm{Abs}-404-\mathrm{BC}}\right)$ (Lack et al., 2012a). The thermal denuder heated the sample flow to $200{ }^{\circ} \mathrm{C}$ and removed the majority of semi-volatile coatings. Following Lack et al. (2012b), non-BC absorption is reported here in the form of a mass absorption efficiency (MAE). We stress that all MAE values presented refer to non-BC absorption at $404 \mathrm{~nm}$ wavelength. The experimentally observed total non-BC MAE was determined using Eq. (2), and includes contributions from both $\mathrm{BC}_{\mathrm{Int}}$ and $\mathrm{BrC}\left(\mathrm{MAE}_{\mathrm{BCInt}+\mathrm{BrC}}\right)$.

$\mathrm{MAE}_{\mathrm{BCInt}+\mathrm{BrC}}=\frac{b_{\mathrm{Abs}-404}-b_{\mathrm{Abs}-404-\mathrm{BC}}}{m_{\text {non- } \mathrm{BC}}}=\frac{b_{\mathrm{Abs}-404-\text { non-BC }}}{m_{\text {non-BC }}}$

The MAE of the non-BC mass with the effects of $\mathrm{BC}$ internal mixing removed $\left(\mathrm{MAE}_{\mathrm{BrC}}\right)$ was calculated independently of the AAE method. Briefly, measured size distributions of the $\mathrm{BC}$ core and coatings were used with Mie theory to calculate absorption at a wavelength where only absorption from BC contributed. Comparison of model and PAS-measured absorption at this wavelength enabled the fraction of non-BC material internally mixed with $\mathrm{BC}$ to be determined. This information was used in subsequent Mie calculations to determine the contribution of coating enhancements to absorption at $404 \mathrm{~nm}\left(\mathrm{BC}_{\text {Int }}\right)$. This procedure enabled the complete attribution of absorption between $\mathrm{BC}, \mathrm{BC}_{\mathrm{Int}}$ and $\mathrm{BrC}$ at this wavelength. All calculations assumed that particles and $\mathrm{BC}$ cores were spherical. There is evidence supporting this assumption from previous studies of particles from inefficient combustion such as biomass burning (Alexander et al., 2008; Chakrabarty et al., 2010; Lewis et al., 2008) and from comparisons of spherical and fractal particle optical modelling (e.g. Chakrabarty et al., 2007). Uncertainties in the calculated $\mathrm{MAE}_{\mathrm{BrC}}$ were estimated to not exceed $20 \%$. Further details can be found in Lack et al. (2012b).

The contribution of dust to total absorption in the biomass plume was assumed minimal due to observations of low background levels of aerosol extinction and absorption measured under conditions not strongly influenced by the biomass plume, and sample mass size distributions that peaked in the accumulation mode at approximately $300 \mathrm{~nm}$.

The AAE attribution method was applied to the same data set to determine the MAE using four different AAE values for $\mathrm{BC}_{\text {Int }}$ : 0.55 (extreme lower limit; Bahadur et al., 2012), 1.0 (community standard), 1.7 (upper limit; Gyawali 


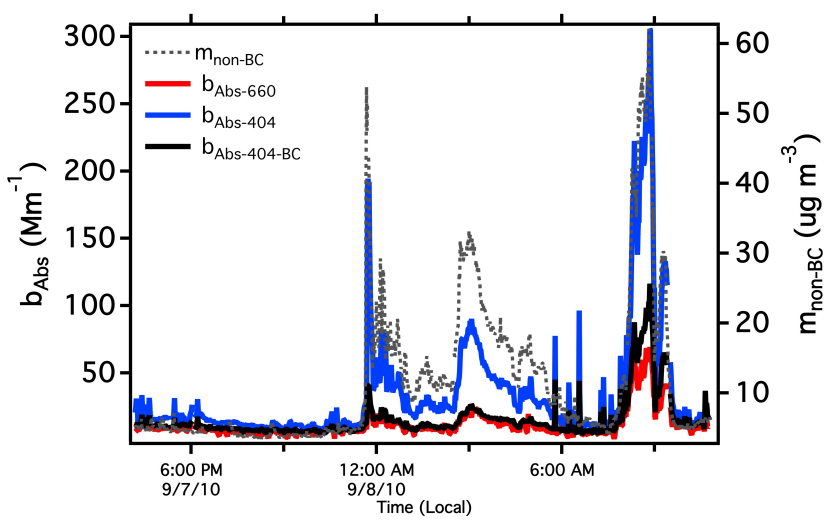

Fig. 3. Time series of measured $404 \mathrm{~nm}$ and $658 \mathrm{~nm}$ absorption of ambient particles (blue and red lines), $404 \mathrm{~nm}$ thermo-denuded absorption (black) and non-refractory aerosol mass (dashed grey line).

et al. (2009) and Lack and Cappa, 2010), and 1.2. This last value represents a Mie modelled average AAE for BC coated in non-absorbing material derived from the same modelling work that removed absorption by internal mixing. All AAEs used were for the wavelength pair $404 \mathrm{~nm}$ and $658 \mathrm{~nm}$.

\subsection{Results}

In this section we compare $\mathrm{BrC}$ absorption values derived from both direct attribution and AAE methods. All absorption values are presented using the MAE.

Absorption measurements for this forest fire revealed significant contributions from both internal mixing of $\mathrm{BC}$ and absorption by $\mathrm{BrC}$ to total absorption (Fig. 3 and Lack et al., 2012b). The two AAE-independent MAE values (MAE $\mathrm{BCInt}_{\mathrm{BrC}}$ and $\mathrm{MAE}_{\mathrm{BrC}}$ ) are compared to those calculated using the AAE attribution method. Histograms of all MAEs are shown in Fig. 4, and the mean and standard deviations shown in Table 1.

In order to make a quantitative assessment of the differences between these methods, we calculated a point-by-point percentage difference between the $\mathrm{MAE}_{\mathrm{BrC}}$ time series and those for $\mathrm{MAE}_{\mathrm{AAE}-0.55}, \mathrm{MAE}_{\mathrm{AAE}-1.0}, \mathrm{MAE}_{\mathrm{AAE}-1.2}$ and $M A E_{A A E-1.7}$. Using this information the mean difference was calculated ( $\triangle \mathrm{MAE} \%$ shown in Table 1$)$. A negative $\triangle \mathrm{MAE} \%$ indicates that, on average, the attributed MAE was less than $\mathrm{MAE}_{\mathrm{BrC}}$. We recognize that the $\triangle \mathrm{MAE} \%$ distributions for each MAE AAE trial had different characteristic shapes, and therefore the mean does not provide a truly representative statistic for comparing trials. However, despite this limitation it still serves as a useful general metric.

The attributed $\mathrm{MAE}_{\mathrm{AAE}-1.0}, \mathrm{MAE}_{\mathrm{AAE}-1.2}$, and $\mathrm{MAE}_{\mathrm{AAE}-1.7}$ all show values below zero, with the fraction of MAE values $<0$ increasing with the assumed AAE used. Uncertainty in the absorption measurements $( \pm 5 \%)$ used to derive these quantities suggests that some negative MAE values may be expected. However, observation of a

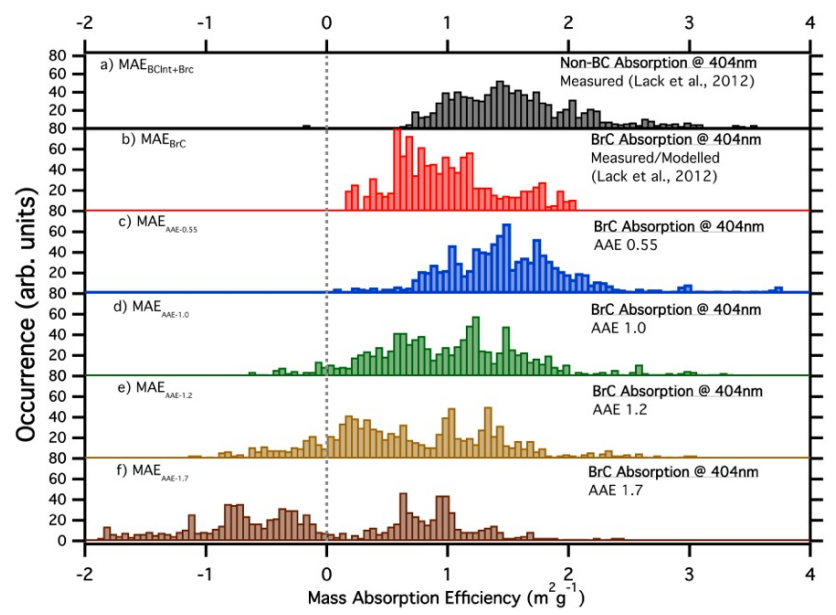

Fig. 4. Histograms of measured and calculated mass absorption efficiency of NR-PM. (a) MAE $\mathrm{BCInt}_{\mathrm{BrC}}$ : measured MAE including internal mixing and $\mathrm{BrC}$, (b) MAE $\mathrm{BrC}_{\mathrm{B}}$ : MAE of just $\mathrm{BrC}$ from Lack et al. (2012), and the MAE of BrC using the AAE attribution method using (c) $\mathrm{AAE}=0.55$, (d) $\mathrm{AAE}=1.0$, (e) $\mathrm{AAE}=1.2$, and (f) $\mathrm{AAE}=1.7$.

progressively larger number of negative MAE values as the assumed AAE increases is likely an indication that the chosen AAE is less reasonable.

The MAE derived using AAE of 0.55 , which has been assessed as an extreme lower limit, is similar to $\mathrm{MAE}_{\mathrm{BCInt}+\mathrm{BrC}}$. However, it is important to recognize that that the $\mathrm{MAE}_{\mathrm{BCInt}+\mathrm{BrC}}$ includes absorption by internal mixing, whereas the attributed $\mathrm{MAE}_{\mathrm{AAE}-0.55}$ does not. Given that the primary objective of this case study is to compare the absorption contribution of just $\mathrm{BrC}$, it is more appropriate to compare AAE-attributed values to $\mathrm{MAE}_{\mathrm{BrC}}$, rather than $\mathrm{MAE}_{\mathrm{BCInt}+\mathrm{BrC}}$. MAE $\mathrm{AAE}_{\mathrm{A}-0.55}$ shows an average overestimation compared to $\mathrm{MAE}_{\mathrm{BrC}}$ of $56 \%$. At the other end of the spectrum, using the AAE of 1.7 produces a difference of $-104 \%$ in addition to yielding a much wider distribution and a substantially larger number of negative values. Both of these AAEs do not attribute absorption correctly.

The best agreement between the AAE attribution method and $\mathrm{MAE}_{\mathrm{BrC}}$ is obtained using $\mathrm{AAE}=1$ (average $\mathrm{MAE}_{\mathrm{AAE}-1.0}$ is $1 \%$ lower than $\mathrm{MAE}_{\mathrm{BrC}}$ ). This result would appear to support the use of the AAE absorption attribution method with $\mathrm{AAE}=1$. However, as stated previously, based upon the observations the most likely $\mathrm{AAE}$ for $\mathrm{BC}_{\mathrm{Int}}$ in this fire was $\sim 1.2$. As such, it appears that the good agreement between $\mathrm{MAE}_{\mathrm{AAE}-1.0}$ and $\mathrm{MAE}_{\mathrm{BrC}}$ was fortuitous. Using the constrained $\mathrm{BC}_{\text {Int }} \mathrm{AAE}$ of 1.2 , the MAE was $-34 \%$ lower than $\mathrm{MAE}_{\mathrm{BrC}}$. Using the most probable range of $\mathrm{AAE}$ values for $\mathrm{BC}_{\text {Int }}$ found in literature $(1.1 \pm 0.3)$, the potential differences between the AAE modelled MAE and $\mathrm{MAE}_{\mathrm{BrC}}$ were $+20 \%$ to $-60 \%$ (interpolated from $\triangle \mathrm{MAE} \%$ in Table 1). 
Table 1. Measured and modelled mass absorption efficiencies (404 nm), and calculated differences.

\begin{tabular}{lrrrrrr}
\hline & $\mathrm{BC}_{\mathrm{Int}}+\mathrm{BrC}$ & $\mathrm{BrC}$ & $\mathrm{AAE}=0.55$ & $\mathrm{AAE}=1$ & $\mathrm{AAE}=1.2$ & $\mathrm{AAE}=1.7$ \\
\hline $\mathrm{MAE}\left(\mathrm{m}^{2} \mathrm{~g}^{-1}\right)$ & $1.58 \pm 0.60$ & $0.98 \pm 0.45$ & $1.54 \pm 0.63$ & $0.99 \pm 0.75$ & $0.66 \pm 0.83$ & $-0.05 \pm 1.04$ \\
$\Delta \mathrm{MAE} \%$ & & $0 \%$ & $56 \%$ & $-1 \%$ & $-34 \%$ & $-104 \%$ \\
\hline
\end{tabular}

These results provide some indication of the range of uncertainty that arises from the choice of AAE used for $\mathrm{BrC}$ absorption attribution. At worst, differences of $50 \%$ to $100 \%$ in attributed MAE were observed in this case study. Even when using our best estimate of the true $\mathrm{BC}_{\text {Int }} \mathrm{AAE}$ for this case study, an average disagreement of $34 \%$ between cases was found.

\section{Summary}

The attribution of short-wavelength light absorption to black and brown carbon has commonly been achieved using the absorption Ångström exponent (AAE) relationship, assuming an AAE for externally mixed black carbon $\left(\mathrm{BC}_{\mathrm{Ext}}\right)$ of unity, and assuming that internal mixing of $\mathrm{BC}\left(\mathrm{BC}_{\mathrm{Int}}\right)$ does not alter AAE. Theoretical investigations and literature values for $\mathrm{BC}_{\mathrm{Ext}}$ and $\mathrm{BC}_{\text {Int }}$ (Fig. 2a) suggest that this assumption can lead to modest uncertainty in attributed short wavelength $\mathrm{BC}_{\mathrm{Ext}}$ or $\mathrm{BC}_{\text {Int }}$ absorption of $+7 \%$ to $-22 \%$. This uncertainty will contribute to uncertainties in attributed $\mathrm{BrC}$ absorption, which is dependent on the absolute amount of $\mathrm{BrC}$ present. For example, uncertainties in attributed $\mathrm{BrC}$ absorption will be $\leq \pm 33 \%$, only when $\mathrm{BrC}$ comprises $23 \%$ to $41 \%$ of total absorption, assuming an absorption measurement uncertainty of $\pm 5 \%$. For the biomass-burning case study presented, which is the most likely environment for the occurrence of strongly absorbing $\mathrm{BrC}, 60 \%$ to $80 \%$ of absorption was due to $\mathrm{BrC}$, making the $\mathrm{AAE}$ attribution method viable.

For the same case study, we found that the AAE attribution method produced differences in attributed $\mathrm{BrC}$ absorption compared to direct analyses that did not use the AAE approach. When using an AAE of 1 , as is often done, the average difference between the $\mathrm{BrC}$ mass absorption efficiency (MAE) calculated using the AAE and AAE-independent method was close to zero. However, the use of AAE $=1$ for this system was likely not justified, given that the system contained BC coated in significant amounts of organic matter, which would have yielded an AAE (without the inclusion of brown carbon absorption) of at least 1.2. When this AAE was used to attribute absorption, an underestimation in BrC MAE of $-34 \%$ was found. This underestimation compounds the overall uncertainty of the attributed absorption by $\mathrm{BrC}$.

Absorbing particles emitted from the same source will likely display a range of AAE based upon size, coatings and composition, which is very likely to change as atmospheric transport and processing occurs. Evolution of these AAE distributions will lead to evolving uncertainties in attributed $\mathrm{BrC}$ absorption when using the AAE method. Although not considered here, the attribution of absorption to dust (in addition to absorption due to $\mathrm{BC}_{\mathrm{Int}}$ ) will add further uncertainty to the attribution of $\mathrm{BrC}$.

We therefore caution against the general application of the AAE method for absorption attribution without careful consideration of uncertainty propagation. In order to minimize uncertainties, the technique should only be applied when a significant fraction of the total absorption is sourced from $\mathrm{BrC}$, and when the $\mathrm{AAE}$ of $\mathrm{BC}_{\mathrm{Ext}}$ or $\mathrm{BC}_{\mathrm{Int}}$ is constrained.

Acknowledgements. Thanks are owed to C. D. Cappa (University of California, Davis) and C. Brock (NOAA) for helpful discussions. Support was provided by the NOAA Climate Program Office, and the NOAA Atmospheric Composition and Climate Program.

Edited by: T. Kirchstetter

\section{References}

Alexander, D. T. L., Crozier, P. A., and Anderson, J. R.: Brown Carbon Spheres in East Asian Outflow and their Optical Properties, Science, 321, 833-836, 2008.

Andreae, M. O. and Gelencsér, A.: Black carbon or brown carbon? The nature of light-absorbing carbonaceous aerosols, Atmos. Chem. Phys., 6, 3131-3148, doi:10.5194/acp-6-3131-2006, 2006.

Ångström, A.: On the Atmospheric Transmission of Sun Radiation and on Dust in the Air, Geografika Ann, 11, 156-166, 1929.

Arola, A., Schuster, G., Myhre, G., Kazadzis, S., Dey, S., and Tripathi, S. N.: Inferring absorbing organic carbon content from AERONET data, Atmos. Chem. Phys., 11, 215-225, doi:10.5194/acp-11-215-2011, 2011.

Bahadur, E., Praveen, P. S., Xu, Y., and Ramanathan, V.: Solar absorption by elemental and brown carbon determined from spectral observations, P. Natl. A. Sci., 109, 17366-17371, 2012.

Bahreini, R., Ervens, B., Middlebrook, A. M., Warneke, C., de Gouw, J. A., DeCarlo, P. F., Jimenez, J. L., Brock, C. A., Neuman, J. A., Ryerson, T. B., Stark, H., Atlas, E., Brioude, J., Fried, A., Holloway, J. S., Peischl, J., Richter, D., Walega, J., Weibring, P., Wollny, A. G., and Fehsenfeld, F. C.: Organic aerosol formation in urban and industrial plumes near Houston and Dallas, Texas, J. Geophys. Res., 114, D00F16, doi:10.1029/2008jd011493, 2009.

Bergstrom, R. W., Russell, P. B., and Hignett, P.: Wavelength Dependence of the Absorption of Black Carbon Particles: Predictions and Results from the TARFOX Ex- 
periment and Implications for the Aerosol Single Scattering Albedo, J. Atmos. Sci., 59, 567-577, doi:10.1175/15200469(2002)059<0567:WDOTAO>2.0.CO;2, 2002.

Bergstrom, R. W., Pilewskie, P., Pommier, J., Rabbette, M., Russell, P. B., Schmid, B., Redemann, J., Higurashi, A., Nakajima, T., and Quinn, P. K.: Spectral absorption of solar radiation by aerosols during ACE-Asia, J. Geophys. Res., 109, D19S15, doi:10.1029/2003jd004467, 2004.

Bergstrom, R. W., Pilewskie, P., Russell, P. B., Redemann, J., Bond, T. C., Quinn, P. K., and Sierau, B.: Spectral absorption properties of atmospheric aerosols, Atmos. Chem. Phys., 7, 5937-5943, doi:10.5194/acp-7-5937-2007, 2007.

Bohren, C. F. and Huffman, D. R.: Absorption and Scattering of Light by Small Particles, John Wiley \& Sons, Inc, 530 pp., 1983.

Bond, T., Habib, G., and Bergstrom, R. W.: Limitations in the Enhancement of Visible Light Absorption Due to Mixing State, J. Geophys. Res., 111, D20211, doi:10.1029/2006JD007315, 2006.

Bond, T. C., Doherty, S. J., Fahey, D. W., Forster, P. M., Berntsen, T., DeAngelo, B. J., Flanner, M. G., Ghan, S., Kärcher, B., Koch, D., Kinne, S., Kondo, Y., Quinn, P. K., Sarofim, M. C., Schultz, M. G., Schulz, M., Venkataraman, C., Zhang, H., Zhang, S., Bellouin, N., Guttikunda, S. K., Hopke, P. K., Jacobson, M. Z., Kaiser, J. W., Klimont, Z., Lohmann, U., Schwarz, J. P., Shindell, D., Storelvmo, T., Warren, S. G., and Zender, C. S.: Bounding the role of black carbon in the climate system: A scientific assessment, J. Geophys. Res.-Atmos., 118, 5380-5552, doi:10.1002/jgrd.50171, 2013.

Cappa, C. D., Onasch, T. B., Massoli, P., Worsnop, D. R., Bates, T. S., Cross, E. S., Davidovits, P., Hakala, J., Hayden, K. L., Jobson, B. T., Kolesar, K. R., Lack, D. A., Lerner, B. M., Li, S.-M., Mellon, D., Nuaaman, I., Olfert, J. S., Petäjä, T., Quinn, P. K., Song, C., Subramanian, R., Williams, E. J., and Zaveri, R. A.: Radiative Absorption Enhancements Due to the Mixing State of Atmospheric Black Carbon, Science, 337, 1078-1081, doi:10.1126/science.1223447, 2012.

Cazorla, A., Bahadur, R., Suski, K. J., Cahill, J. F., Chand, D., Schmid, B., Ramanathan, V., and Prather, K. A.: Relating aerosol absorption due to soot, organic carbon, and dust to emission sources determined from in-situ chemical measurements, Atmos. Chem. Phys., 13, 9337-9350, doi::10.5194/acp-13-9337-2013, 2013.

Chakrabarty, R. K., Moosmüller, H., Arnott, W. P., Garro, M. A., Slowik, J. G., Cross, E. S., Han, J.-H., Davidovits, P., Onasch, T. B., and Worsnop, D. R.: Light Scattering and Absorption by Fractal-Like Carbonaceous Chain Aggregates: Comparison of Theories and Experiment, Appl. Optics, 46, 6990-7006, 2007.

Chakrabarty, R. K., Moosmüller, H., Chen, L.-W. A., Lewis, K., Arnott, W. P., Mazzoleni, C., Dubey, M. K., Wold, C. E., Hao, W. M., and Kreidenweis, S. M.: Brown carbon in tar balls from smoldering biomass combustion, Atmos. Chem. Phys., 10, 63636370, doi:10.5194/acp-10-6363-2010, 2010.

Chung, C. E., Kim, S.-W., Lee, M., Yoon, S.-C., and Lee, S.: Carbonaceous aerosol AAE inferred from in-situ aerosol measurements at the Gosan $\mathrm{ABC}$ super site, and the implications for brown carbon aerosol, Atmos. Chem. Phys., 12, 6173-6184, doi:10.5194/acp-12-6173-2012, 2012.

Clarke, A., McNaughton, C., Kapustin, V., Shinozuka, Y., Howell, S., Dibb, J., Zhou, J., Anderson, B., Brekhovskikh, V., Turner, H., and Pinkerton, M.: Biomass Burning and Pollution Aerosol over North America: Organic Components and Their Influence on Spectral Optical Properties and Humidification Response, J. Geophys. Res., 112, D12S18, doi:10.1029/2006jd007777, 2007.

Corr, C. A., Hall, S. R., Ullmann, K., Anderson, B. E., Beyersdorf, A. J., Thornhill, K. L., Cubison, M. J., Jimenez, J. L., Wisthaler, A., and Dibb, J. E.: Spectral absorption of biomass burning aerosol determined from retrieved single scattering albedo during ARCTAS, Atmos. Chem. Phys., 12, 10505-10518, doi:10.5194/acp-12-10505-2012, 2012.

Cross, E. S., Onasch, T., Ahern, A. T., Wrobel, W., Slowik, J., Olfert, J., Lack, D. A., Massoli, P., Cappa, C. D., Schwarz, J. P., Spackman, J. R., Fahey, D. W., Sedlacek, A., Trimborn, A., Jayne, J., Freedman, A., Williams, L., Ng, N., Mazzoleni, C., Dubey, M., Brem, B., Kok, G., Subramanian, R., Freitag, S., Clarke, T., D., T., Marr, L., Kolb, C., Worsnop, D., and Davidovits, P.: Soot Particle Studies - Instrument Inter-Comparison Project Overview, Aerosol Sci. Tech., 44, 592-611, 2010.

Esposito, F., Calvello, M. R., Gueguen, E., and Pavese, G.: A new algorithm for brown and black carbon identification and organic carbon detection in fine atmospheric aerosols by a multi-wavelength Aethalometer, Atmos. Meas. Tech. Discuss., 5, 1003-1027, doi:10.5194/amtd-5-1003-2012, 2012.

Favez, O., Alfaro, S. C., Sciare, J., Cachier, H., and Abdelwahab, M. M.: Ambient measurements of light-absorption by agricultural waste burning organic aerosols, J. Aerosol. Sci., 40, 613-620, 2009.

Fialho, P., Hansen, A. D. A., and Honrath, R. E.: Absorption coefficients by aerosols in remote areas: a new approach to decouple dust and black carbon absorption coefficients using sevenwavelength Aethalometer data, J. Aerosol Sci., 36, 267-282, doi:10.1016/j.jaerosci.2004.09.004, 2005.

Flowers, B. A., Dubey, M. K., Mazzoleni, C., Stone, E. A., Schauer, J. J., Kim, S.-W., and Yoon, S. C.: Optical-chemicalmicrophysical relationships and closure studies for mixed carbonaceous aerosols observed at Jeju Island; 3-laser photoacoustic spectrometer, particle sizing, and filter analysis, Atmos. Chem. Phys., 10, 10387-10398, doi:10.5194/acp-10-10387-2010, 2010.

Fuller, K. A., Malm, W. C., and Kreidenweis, S. M.: Effects of Mixing on Extinction by Carbonaceous Particles, J. Geophys. Res., 104, 15941-15954, doi:10.1029/1998JD100069, 1999.

Gadhavi, H. and Jayaraman, A.: Absorbing aerosols: contribution of biomass burning and implications for radiative forcing, Ann Geophys., 28, 103-111, doi:10.5194/angeo-28-103-2010, 2010.

Gyawali, M., Arnott, W. P., Lewis, K., and Moosmüller, H.: In situ aerosol optics in Reno, NV, USA during and after the summer 2008 California wildfires and the influence of absorbing and non-absorbing organic coatings on spectral light absorption, Atmos. Chem. Phys., 9, 8007-8015, doi:10.5194/acp-9-8007-2009, 2009.

Herich, H., Hueglin, C., and Buchmann, B.: A 2.5 year's source apportionment study of black carbon from wood burning and fossil fuel combustion at urban and rural sites in Switzerland, Atmos. Meas. Tech., 4, 1409-1420, doi:10.5194/amt-4-1409-2011, 2011.

Jacobson, M. Z.: Strong radiative heating due to the mixing state of black carbon in atmospheric aerosols, Nature, 409, 695-697, 2001.

Kaufman, Y. J., Martins, J. V., Remer, L. A., Schoeberl, M. R., and Yamasoe, M. A.: Satellite Retrieval of Aerosol Absorption 
over the Oceans Using Sunglint, Geophys. Res. Lett., 29, 1928, doi:10.1029/2002GL015403, 2002.

Kirchstetter, T. W., Novakov, T., and Hobbs, P. V.: Evidence that the Spectral Dependence of Light Absorption by Aerosols is Affected by Organic Carbon, J. Geophys. Res.-Atmos., 109, D21208, doi:10.1029/2004JD004999, 2004.

Lack, D. A. and Cappa, C. D.: Impact of brown and clear carbon on light absorption enhancement, single scatter albedo and absorption wavelength dependence of black carbon, Atmos. Chem. Phys., 10, 4207-4220, doi:10.5194/acp-10-4207-2010, 2010.

Lack, D. A., Cappa, C. D., Covert, D. S., Baynard, T., Massoli, P., Sierau, B., Bates, T. S., Quinn, P. K., Lovejoy, E. R., and Ravishankara, A. R.: Bias in Filter Based Aerosol Light Absorption Measurements Due to Organic Aerosol Loading: Evidence from Ambient Measurements, Aerosol Sci. Tech., 42, 1033-1041, 2008.

Lack, D. A., Cappa, C. D., Cross, E. S., Massoli, P., Ahern, A. T., Davidovits, P., and Onasch, T. B.: Absorption Enhancement of Coated Absorbing Aerosols: Validation of the Photo-Acoustic Technique for Measuring the Enhancement, Aerosol Sci. Tech., 43, 1006-1012, 2009.

Lack, D., Langridge, J., Richardson, M., Cappa, C. D., Law, D., and Murphy, D. M.: Aircraft instrumentation for comprehensive characterization of aerosol optical properties, Part 2: Black and brown carbon absorption and absorption enhancement measured with photo acoustic spectroscopy, Aerosol Sci. Tech., 46, 555568, 2012a.

Lack, D. A., Langridge, J. M., Bahreini, R., Cappa, C. D., Middlebrook, A. M., and Schwarz, J. P.: Brown carbon and internal mixing in biomass burning particles, P. Natl. Acad. Sci., doi:10.1073/pnas.1206575109, 2012 b.

Lewis, K., Arnott, W. P., Moosmüller, H., and Wold, C. E.: Strong spectral variation of biomass smoke light absorption and single scattering albedo observed with a novel dual-wavelength photoacoustic instrument, J. Geophys. Res., 113, D16203, doi:10.1029/2007jd009699, 2008.

Li, Z., Zhao, X., Kahn, R., Mishchenko, M., Remer, L., Lee, K.-H., Wang, M., Laszlo, I., Nakajima, T., and Maring, H.: Uncertainties in satellite remote sensing of aerosols and impact on monitoring its long-term trend: a review and perspective, Ann. Geophys., 27, 2755-2770, doi:10.5194/angeo-27-2755-2009, 2009.

McNaughton, C. S., Clarke, A. D., Freitag, S., Kapustin, V. N., Kondo, Y., Moteki, N., Sahu, L., Takegawa, N., Schwarz, J. P., Spackman, J. R., Watts, L., Diskin, G., Podolske, J., Holloway, J. S., Wisthaler, A., Mikoviny, T., de Gouw, J., Warneke, C., Jimenez, J., Cubison, M., Howell, S. G., Middlebrook, A., Bahreini, R., Anderson, B. E., Winstead, E., Thornhill, K. L., Lack, D., Cozic, J., and Brock, C. A.: Absorbing aerosol in the troposphere of the Western Arctic during the 2008 ARCTAS/ARCPAC airborne field campaigns, Atmos. Chem. Phys., 11, 7561-7582, doi:10.5194/acp-11-7561-2011, 2011.

Meloni, D., di Sarra, A., Pace, G., and Monteleone, F.: Aerosol optical properties at Lampedusa (Central Mediterranean). 2. Determination of single scattering albedo at two wavelengths for different aerosol types, Atmos. Chem. Phys., 6, 715-727, doi:10.5194/acp-6-715-2006, 2006.

Moosmüller, H. and Arnott, W. P.: Particle Optics in the Rayleigh Regime, Japca J. Air Waste Ma., 59, 1028-1031, 2009.
Moosmüller, H., Chakrabarty, R. K., Ehlers, K. M., and Arnott, W. P.: Absorption Ångström coefficient, brown carbon, and aerosols: basic concepts, bulk matter, and spherical particles, Atmos. Chem. Phys., 11, 1217-1225, doi:10.5194/acp-11-12172011, 2011.

Rizzo, L. V., Correia, A. L., Artaxo, P., Procópio, A. S., and Andreae, M. O.: Spectral dependence of aerosol light absorption over the Amazon Basin, Atmos. Chem. Phys., 11, 8899-8912, doi:10.5194/acp-11-8899-2011, 2011.

Rosen, H., Hansen, A. D. A., Gundel, L., and Novakov, T.: Identification of the optically absorbing component in urban aerosols, Appl. Optics, 17, 3859-3861, 1978.

Russell, P. B., Bergstrom, R. W., Shinozuka, Y., Clarke, A. D., DeCarlo, P. F., Jimenez, J. L., Livingston, J. M., Redemann, J., Dubovik, O., and Strawa, A.: Absorption Ångstrom Exponent in AERONET and related data as an indicator of aerosol composition, Atmos. Chem. Phys., 10, 1155-1169, doi:10.5194/acp-101155-2010, 2010.

Sandradewi, J., Prévôt, A. S. H., Alfarra, M. R., Szidat, S., Wehrli, M. N., Ruff, M., Weimer, S., Lanz, V. A., Weingartner, E., Perron, N., Caseiro, A., Kasper-Giebl, A., Puxbaum, H., Wacker, L., and Baltensperger, U.: Comparison of several wood smoke markers and source apportionment methods for wood burning particulate mass, Atmos. Chem. Phys. Discuss., 8, 8091-8118, doi:10.5194/acpd-8-8091-2008, 2008a.

Sandradewi, J., Prevot, A. S. H., Szidat, S., Perron, N., Alfarra, M. R., Lanz, V. A., Weingartner, E., and Baltensperger, U.: Using Aerosol Light Absorption Measurements for the Quantitative Determination of Wood Burning and Traffic Emission Contributions to Particulate Matter, Envir. Sci. Tech., 42, 3316-3323, doi:10.1021/es702253m, 2008b.

Schnaiter, M., Linke, M., Möhler, O., Naumann, K.-H., Saathoff, H., Wagner, R., Schurath, U., and Wehner, B.: Absorption amplification of black carbon internally mixed with secondary organic aerosol, J. Geophys. Res., 110, D19204, doi:10.1029/2005JD006046, 2005.

Schuster, G. L., Dubovik, O., Holben, B. N., and Clothiaux, E. E.: Inferring black carbon content and specific absorption from Aerosol Robotic Network (AERONET) aerosol retrievals, J. Geophys. Res., 110, D10S17, doi:10.1029/2004jd004548, 2005.

Schwarz, J. P., Gao, R. S., Spackman, J. R., Watts, L. A., Thomson, D. S., Fahey, D. W., Ryerson, T. B., Peischl, J., Holloway, J. S., Trainer, M., Frost, G. J., Baynard, T., Lack, D. A., de Gouw, J. A., Warneke, C., and Del Negro, L. A.: Measurement of the Mixing State, Mass, and Optical Size of Individual Black Carbon Particles in Urban and Biomass Burning Emissions, Geophys. Res. Lett., 35, L13810, doi:10.1029/2008GL033968, 2008.

Subramanian, R., Roden, C. A., Boparai, P., and Bond, T. C.: Yellow Beads and Missing Particles: Trouble Ahead for Filter-Based Absorption Measurements, Aerosol Sci. Tech., 41, 630-637, 2007.

Tesche, M., Muller, D., Gross, S., Ansmann, A., Althausen, D., Freudenthaler, V., Weinzierl, B., Veira, A., and Petzold, A.: Optical and microphysical properties of smoke over Cape Verde inferred from multiwavelength lidar measurements, Tellus B, 63, doi:10.1111/j.1600-0889.2011.00549.x, 2011.

Updyke, K. M., Nguyen, T. B., and Nizkorodov, S. A.: Formation of brown carbon via reactions of ammonia with secondary organic aerosols from biogenic and anthropogenic precursors, At- 
mos. Environ., 63, 22-31, doi:10.1016/j.atmosenv.2012.09.012, 2012.

Virkkula, A., Ahlquist, N. C., Covert, D. S., Arnott, W. P., Sheridan, P. J., Quinn, P. K., and Coffman, D. J.: Modification, calibration and a field test of an instrument for measuring light absorption by particles, Aerosol Sci. Tech., 39, 68-83, 2005.

Wang, X., Doherty, S. J., and Huang, J.: Black carbon and other light-absorbing impurities in snow across Northern China, J. Geophys. Res.-Atmos., 118, 1471-1492, doi:10.1029/2012jd018291, 2013.

Weinzierl, B., Sauer, D., Esselborn, M., Petzold, A., Veira, A., Rose, M., Mund, S., Wirth, M., Ansmann, A., Tesche, M., Gross, S., and Freudenthaler, V.: Microphysical and optical properties of dust and tropical biomass burning aerosol layers in the Cape Verde region - an overview of the airborne in situ and lidar measurements during SAMUM-2, Tellus B, 63, 589-618, doi:10.1111/j.1600-0889.2011.00566.x, 2011.
Yang, M., Howell, S. G., Zhuang, J., and Huebert, B. J.: Attribution of aerosol light absorption to black carbon, brown carbon, and dust in China - interpretations of atmospheric measurements during EAST-AIRE, Atmos. Chem. Phys., 9, 2035-2050, doi:10.5194/acp-9-2035-2009, 2009.

Zhang, R., Khalizov, A. F., Pagels, J., Zhang, D., Xue, H., and McMurry, P. H.: Variability in morphology, hygroscopicity, and optical properties of soot aerosols during atmospheric processing, Proc. Natl. A. Sci., 105, 10291-10296, 2008. 